\title{
USING THE MESSENGER SOFTWARE OPPORTUNITIES IN DISTANCE EDUCATION
}

\author{
USO DAS OPORTUNIDADES DO SOFTWARE MESSENGER NA EDUCAÇÃO A \\ DISTÂNCIA
}

\author{
USO DE LAS OPORTUNIDADES DEL SOFTWARE MESSENGER EN EDUCACIÓN A \\ DISTANCIA
}

\author{
Timur R. FAZLIAKHMETOV ${ }^{1}$ \\ Leila L. SALEKHOVA ${ }^{2}$ \\ Gulnur I. MUHUTDINOVA ${ }^{3}$ \\ Ramiz M. ASLANOV
}

\begin{abstract}
Nowadays, the use of distance learning in the educational process of a university is becoming relevant. The current conditions stimulate and intensify the use of innovative training tools, particularly network software products. This paper analyzed the possibilities and costs of using various digital products in an educational environment. Considering the use of mobile digital solutions for distance learning, as well as the requirements for the development of such tools by teachers who do not have the skills to create software at a professional level. The Telegram messenger example describes the experience of using instant messengers in the learning process, namely, a chat bot was created to organize the control of knowledge of students in a higher educational institution. The original chat bot, which was developed using the Telegram API interface and the Chattera chat bot designer, tests the knowledge and skills of students undergoing "General and professional pedagogy" educational discipline. This study showed that the potential of the messenger is not only in communication between users in the form of sending audio, video, and text messages, but also in its educational capabilities.
\end{abstract}

KEYWORDS: Distance education. Mobile training. Telegram. Chat bot. Chat bot designer.

RESUMO: Atualmente, o uso do ensino a distância no processo educacional de uma universidade está se tornando relevante. As condições atuais estimulam e intensificam o uso de ferramentas de formação inovadoras, em particular, produtos de software de rede. Este trabalho analisou as possibilidades e os custos do uso de vários produtos digitais em um ambiente educacional. Considerando, especialmente, o uso de soluções digitais móveis para

\footnotetext{
${ }^{1}$ Kazan Federal University (KPFU), Kazan - Russia. Teaching Assistant of the Department of Bilingual and Digital Education. ORCID: https://orcid.org/0000-0003-2737-3408. E-mail: fazliahmetovtimur@yandex.ru

${ }^{2}$ Kazan Federal University (KPFU), Kazan - Russia. Professor of the Department of Bilingual and Digital Education. Doctor of Pedagogic Sciences. ORCID: https://orcid.org/0000-0002-8177-3739. E-mail: salekhova2009@gmail.com

3 Kazan Federal University (KPFU), Kazan - Russia. Master of the Department of Bilingual and Digital Education. ORCID: https://orcid.org/0000-0002-7246-5435. E-mail: g.ilnurovna@mail.ru

${ }^{4}$ Azerbaijan National Academy of Sciences (ANAS), Baku - Azerbaijan. Professor of the Department of Mathematical Analysis, Institute of Mathematics and Mechanics of NASA. Doctor of Pedagogical Sciences. Email: rmi@imm.az
}

RPGE- Revista on line de Política e Gestão Educacional, Araraquara, v. 25, n. esp. 1, p. 378-386, mar. $2021 . \quad$ e-ISSN:1519-9029 DOI: https://doi.org/10.22633/rpge.v25iesp.1.14974 
o ensino a distância, bem como os requisitos para o desenvolvimento de tais ferramentas por professores que não possuem as habilidades necessárias para criar software a nível profissional. O exemplo do Telegram messenger descreve a experiência do uso de mensageiros instantâneos no processo de aprendizagem, ou seja, foi criado um chat bot para organizar o controle do conhecimento dos estudantes em uma instituição de ensino superior. O chat bot original, que foi desenvolvido utilizando a interface Telegram API e o designer do Chattera chat bot, testa os conhecimentos e habilidades dos estudantes que se submetem à disciplina educacional "Pedagogia geral e profissional". Este estudo mostrou que o potencial do mensageiro não está apenas na comunicação entre usuários, na forma de envio de mensagens de áudio, vídeo e texto, mas também em suas capacidades educacionais

PALAVRAS-CHAVE: Educação a distância. Formação móvel. Telegram. Chat bot. Designer de chat bot.

RESUMEN: Hoy en día, el uso de la educación a distancia en el proceso educativo de una universidad está cobrando relevancia. Las condiciones actuales estimulan e intensifican el uso de herramientas de formación innovadoras, en particular, productos de software de red. En este trabajo se analizan las posibilidades y costos de utilizar diversos productos digitales en un entorno educativo. En particular, consideran el uso de soluciones digitales móviles para la educación a distancia, así como los requisitos para el desarrollo de dichas herramientas por parte de profesores que no tienen las habilidades para crear software a nivel profesional. El ejemplo de Telegram messenger describe la experiencia de usar mensajería instantánea en el proceso de aprendizaje, es decir, se creó un chat bot para organizar el control del conocimiento de los estudiantes en una institución de educación superior. El chat bot original, que se desarrolló utilizando la interfaz API de Telegram y el diseñador de chat bot Chattera, evalúa los conocimientos y habilidades de los estudiantes de la disciplina educativa de "pedagogía general y profesional". Este estudio mostró que el potencial del mensajero no está solo en comunicación entre usuarios en forma de envío de mensajes de audio, video y texto, pero también en sus capacidades educativas.

PALABRAS CLAVE: Educación a distancia. Entrenamiento móvil. Telegram. Chat bot. Diseñador de chat bot.

\section{Introduction}

Digitalization of various spheres of life leads to their transformation. This trend also affected education, which is the key to the successful development of an individual, nation, state, and the whole society.

The organization of the educational process through innovative forms significantly increases the competitiveness of the university and provides a high-quality, up-to-date level of education. High demands are made on the education system in the process of reform, first of all, on the training of the teaching staff. 
Within the framework of distance learning, which is becoming more and more popular in modern universities, it is advisable to adapt the usual teaching methods that have become classical (DANILOV et al., 2019).

Modern information and communication technologies can intensify traditional forms and methods of training. Multimedia is as much an equal source of information as print media, and thanks to the proliferation of the Internet network, innovative forms of learning are emerging.

The regulatory principles of the educational process organization are changing; the conditions for the implementation of agile personalized learning are created. The possibility of organizing such an educational process taking into account the needs of each student is normatively prescribed in Art. 13 of the Federal Law dated December 29, 2012 No. 273-F3 "On Education in the Russian Federation" (as amended on 24.04.2020): "Various educational technologies are used in the implementation of educational programs, including distance educational technologies, and e-learning” (RUSSIA, 2012).

Distance, or distant, training is a form of training in which all or most of the training procedures are carried out using modern information and telecommunication technologies with the territorial disunity of teachers and their students (POLAT, 2004).

The main types of distance learning platforms are distinguished: TV technology, case technology, and network technologies. These techniques are based on a different degree of interactivity: the training materials are online; both participants in the educational process (teacher, student) have access to information in order perform appropriate actions with it: processing, monitoring, completing tasks, and communicating.

In the classical concept of distance education, more attention is paid to the individual work of students than to collective work. Modern realities dictate new conditions and welladjusted and effective communications are of paramount importance, both in everyday and in educational activities. Therefore, even at the stage of obtaining higher education in a remote way, it is important to develop pair, group and collective forms of interaction between students. These tasks can be realized through innovative forms of distance learning, including online learning technology in the form of a forum or chat.

Online training in the form of a forum or chat is a modern approach to distance learning, which makes the most of the Internet and communication facilities (Zoom, Microsoft Teams, Messenger, etc.), in which dialogue and communication are of paramount importance. 
These transformations both open up for teachers the opportunities for the organization of the educational process and also present some difficulties to them.

The paper considers a non-contact distance learning form for students of Kazan Federal University in a situation where the teacher does not have the opportunity to conduct "full-time" communication with students; that is, the organization of the educational process using digital tools and automation of operations is necessary.

\section{Methods}

When choosing a technological platform for the implementation of non-contact distance learning, we were guided by the principles of didactic engineering developed by M.A. Choshanov:

- It should provide the teacher with rich functionality for the development of educational material, that is, the platform should support different formats and types of information;

- The application should provide ease in the construction of educational material, that is, the creation of educational material should not require special technical skills from teachers.

Practice shows that it is more expedient to create Internet resources on universal platforms compromising between functionality, ease of development and financial costs. In our opinion, such a solution is messengers.

The IT industry is focused on the development of online information processing solutions; such technologies as cloud computing, web 2.0 services, and others have significantly popularized the Internet.

Over the past few years, the number of instant messengers has increased sharply, and the number of their users is increasing. In 2012, the share of sales of mobile computing devices oriented to use the Internet for the first time exceeded the share of sales of desktop personal computers (http://www.json.ru). More and more people have access to the Internet, and for many a computer has become just a "tool" for accessing the Web and solving professional problems. This is due to the fact that mobile devices such as smartphones, tablets, phones, began to compete with stationary personal computers. This happened due to the fact that mobile devices cope no worse than desktop PCs with everyday user requests: searching for information on the Internet, sending mail and messages, creating and editing 
office documents, playing games, communicating on social networks and more. Moreover, the mobile Internet has become more accessible, which has led to the emergence and development of a new direction in education, i.e. mobile learning.

Mobile learning is any educational activity in which portable devices are mainly or exclusively used, they are: "phones, smartphones, tablets, but not ordinary desktop computers" (IVANCHENKO, 2014).

V. A. Kuklev suggests that when choosing a program or application for mobile learning, it is necessary to be guided with the following principles:

Simplicity and accessibility in use: the interface should be familiar to students or can be learned by them in a short time;

Free, so that every student can install such an application at any time without any difficulties;

Wide opportunities that would not be inferior to the capabilities of other services or could be compensated by new ones;

No need to acquire specialized knowledge in the field of information technology for the successful application of the program (KUKLEV, 2010).

After the analysing of a large number of platforms, we came to the conclusion that Telegram meets all of the above requirements as much as possible.

Telegram is a cloud-based instant messenger. Users can send messages and share photos, videos, audio and files of any type. It was developed in 2013 by the brothers Nikolai and Pavel Durov. As of April 2020, Telegram has 400 million active users per month, with at least 1.5 million new users registering daily ( https://telegram.org).

Being a messenger program originally designed to send messages, Telegram has no orientation toward the educational process. However, it has ample opportunities for use in the learning process. First of all, this is the organization of interaction between students during group work, as well as during the creation of a project where it may be necessary to send files and photos, voice notes, create groups and channels. The main forms of organization of training include:

- Groups and group chats. Multi-user groups are suitable for quickly uniting likeminded people and instant communication between them. Developing the main topics of the chat, we can create common projects, organize cooperation to achieve common goals, ask questions and receive answers, conduct conversations and discussions, something important.

- Channels in Telegram. It is the channels, as well as the function of creating chat bots that are not common for messengers (MESSINA, 2016), that make Telegram a very functional and attractive program for organizing the learning process. Channels can be used 
for sharing with many users at once. There are a large number of popular information and educational channels. Also, each teacher (or even a student) can create their own channel, which will become an analogue of the blog or will be designed to present the progress of the project work to all its participants (http://telegram.org).

- Bots in Telegram. Bots are special Telegram accounts created to automatically process and send messages. Users can interact with bots using messages sent via regular or group chats. The bot's logic is controlled using HTTPS requests to simplified methods of the Telegram's API. API (application programming interface) is an application programming interface that allows services to interact, gain access and exchange data (TELEGRAM BOTS FAQ, 2020).

In the age of digital technology and digital capabilities, technology is tailored to be convenient to use. Modern technologies make it possible to solve problems of routine tasks and actions through their automation. One example of such automation is bots.

Research in the field of the creation of Telegram bots is relevant. In his paper, Kruglik (2020) described the creation of a chat bot in Telegram using the PHP programming language. Filonov and Tupikin (2017) developed a chat bot on Telegram to help applicants. Ivanov (2016) highlighted the benefits of chat bots in Telegram and VKontakte for news distribution. The paper by Dasyuk and Veres (2019) describes the use of the Telegram API and I. A. Orekhin (2017) developed the Telegram bot to study English grammar.

\section{Results}

We consider the step-by-step creation of a Telegram bot without applying the skills of programming languages: it will be performed in the form of a test with multiple and single choice answers on the topic "General and professional pedagogy".

First we need to create a bot in Telegram itself using BotFather, which is a special bot that controls bots created by users. It is used to create new bot accounts and manage existing bots (BOTFATHER WEB SERVICE, 2020.).

The bot creation process begins by sending messages to the BotFather bot, which have a special syntax. We must enter a name of the bot and an address where users can find it. After the bot has been pre-configured, it is necessary to fill it with contents and program it for certain actions: displaying a test form to the user. In our case, the Chatforma service is used. After registering at the service and linking the bot to the system, it is necessary to fill it with 
the contents at the "Designer" tab. The chatbot will be filled according to the thematic content of the taught discipline, i.e. "General and professional pedagogy" in our case. Questions on a discipline are of two types: a question with a single choice of answer and a question with multi-choice (two or more answers). The bot implements the identity of a test person by indicating their data. In the Chatforma service, data collection is implemented, in which we can see the information - last name, first name, middle name of the student, date of the testing, and selected answers.

Figure 1 - The educational chat-bot workflow (user-side)

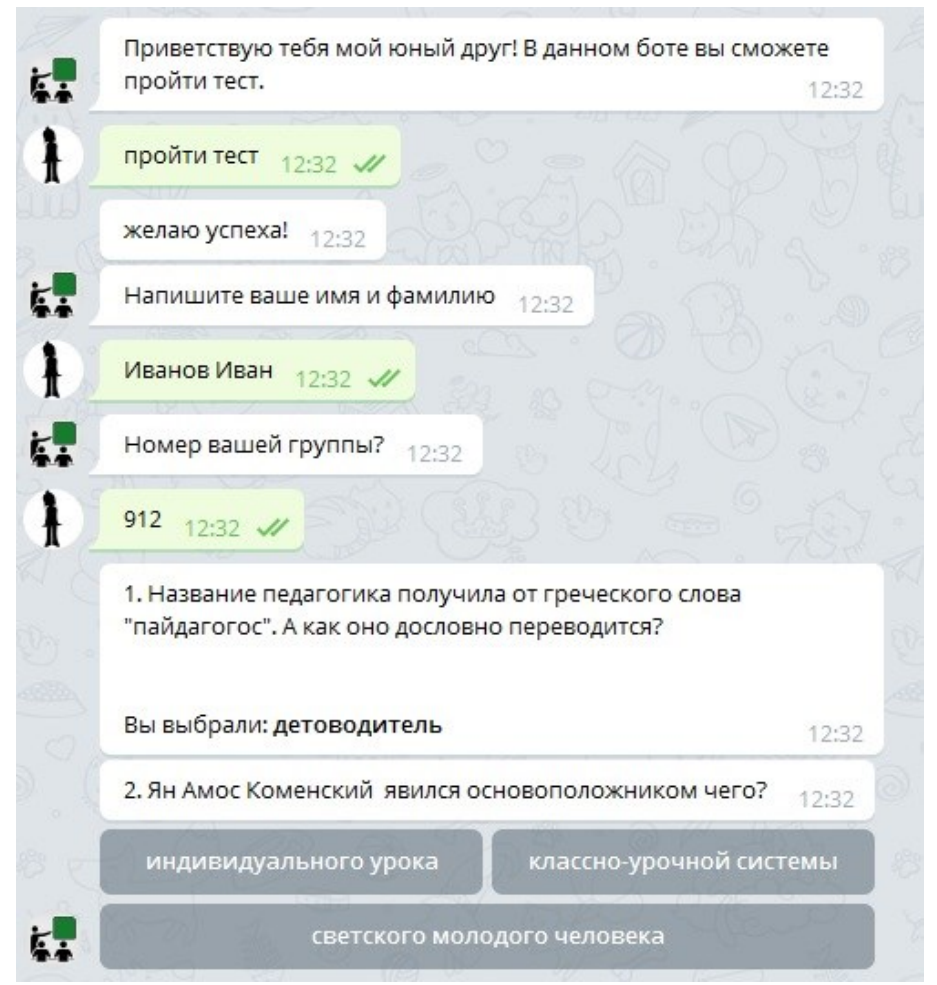

Source: Collection of the authors

\section{Disscussion and conclusions}

Thus, a bot was developed using the example of the Telegram messenger to control knowledge. The development itself does not require programming skills, thereby opening up the possibility of creating such solutions for a wide audience of educators

However, I would like to draw attention to the fact that the Chatforma service is not a completely free product, the ability to use all the functionality of the service is provided only for a certain period. 
Testing showed that students positively perceived the organization of knowledge control using a chat bot. A means of communication familiar to a student has acquired new functions. Also, students do not need to install third-party software tools.

Chat bots are a modern, mobile and additional tool that expands the possibilities of using instant messengers in distance learning.

The study showed that the technological and didactic potential of instant messengers, in particular Telegram, can be integrated into the educational process of the university.

ACKNOWLEDGEMENTS: The work is performed according to the Russian Government Program of Competitive Growth of Kazan Federal University.

\section{REFERENCES}

400 MILLION Users, 20,000 Stickers, Quizzes 2.0 and $€ 400 \mathrm{~K}$ for Creators of Educational Tests. 2020. [Electronic source]. Available: https://telegram.org/blog/400-million?ln=f. Access: 5 may 2020.

BOTFATHER web service. [Electronic source]. Available: https: //tele.gs/botfather. Access: 5 may 2020.

CHOSHANOV, M. Didactic engineering and Informatization of education. In:

CHOSHANOV M. Future-oriented education-Kazan. "Fen” Publishing House, 2016. p. 119-151.

DANILOV, A. et al. Digitalisation trends and blended learning visualisation in modern digital education. International Journal of Innovative Technology and Exploring Engineering, v. 9, n. 1, p. 5109- 5111, nov. 2019. DOI: https://doi.org/10.35940/ijitee.A9207.119119

DASYUK, A. M.; VERES, D. M. Verification system of task solutions with telegram API. Scientific Outlook for the future, Odessa, v. 1, n. 14, p. 41-46, 2019.

FILONOV, D.; TUPIKIN, V. Chatbot for Telegram to help applicants. Notes on computer science and mathematics. Collection of scientific papers, Yaroslavl, p. 152-156, 2017.

IVANCHENKO, D. Managing mobile technologies in the information space of a modern University. Higher education in Russia, n. 7, p. 93-100, 2014.

IVANOV, A. D. Chatbot in Telegram and Vkontakte as a new news distribution channel. Vestnik Volga Univ., v. 1, n. 3, p. 126-132, 2016.

KRUGLIK, R. Creating a chatbot in Telegram. The postulate of the Amur state University, 2020. [Electronic source]. Available: http://e-

postulat.ru/index.php/Postulat/paper/view/2839/2883. Access: 5 may 2020. 
KUKLEV, V. Formation of a mobile learning system in open distance education. 2010. Dissertation (Doctor of Pedagogical Sciences) - Ulyanovsk State Technical University, Ulyanovsk, 2010.

MESSINA, C. Will be the year of conversational commerce. A Medium Corporation, 2016. Available: https://medium.com/chris-messina/2016-will-be-the-year-of-conversationalcommerce-1586e85e3991. Access: 5 may 2020. (2016).

OREHIN. Telegram bot in English. Information technologies in the modern world, Yekaterinburg, p. 119-122, 2017.

POLAT, E. S. Theory and practice of distance learning. Moscow: Publishing Center Academy, 2004. p. 416.

RUSSIA. Federal Law n. 273-FZ, of December 29 of 2012. About education in the Russian Federation. SPS Garant: Editorial from 24 abr. 2020.

RUSSIAN Market of Smartphones and tablet PCs/ J'Son and Partners Management Consultancy. 2016. Available:

http://www.json.ru/ru/poleznye_materialy/free_market_watches/analytics/rossijskij_rynok_s martfonov_i_planshetnyh_pk/. Access: 5 may 2020.

TELEGRAM Bots FAQ. [Electronic source]. Available: http://core.telegram.org/bots/faq. Access: 5 may 2020.

TELEGRAM Homepage. 2020. [Electronic source]. Available: http://telegram.org. Access: 5 may 2020.

\section{How to reference this article}

FAZLIAKHMETOV, T. R.; SALEKHOVA, L. L.; MUHUTDINOVA, G. I.; ASLANOV, R. M. Using the messenger software opportunities in distance education. Revista on line de Política e Gestão Educacional, Araraquara, v. 25, n. esp. 1, p. 378-386, mar. 2021. eISSN:1519-9029. DOI: https://doi.org/10.22633/rpge.v25iesp.1.14974

Submitted: 06/11/2020

Required revisions: $18 / 01 / 2021$

Approved: $23 / 02 / 2021$

Published: 01/03/2021 